\title{
Implementation of Radiation Safety Utilization of Fluoroscopy Baggage Scanner at Port
}

\author{
Sri Mulyati ${ }^{1, *}$, Rini Indrati $^{1}$, Rasyid $^{1}$, Siti Masrochah ${ }^{1}$, Luthfi Rusyadi $^{1}$, Ardi Soesilo Wibowo ${ }^{1}$, and Sudiyono ${ }^{1}$ \\ ${ }^{1}$ Poltekkes Kemenkes Semarang - Indonesia
}

\begin{abstract}
The effort to ensure radiation safety guarantees for officers and the general public on the use of fluoroscopy baggage scanner is used at the port passenger terminal due to using ionizing radiation. The aim to be achieved is to find out the management of the use of ionizing radiation and related radiation protection according to national and international standards. The research method in this study was an observational survey by observing, interviewing and documenting safety facilities and procedures by performing management for operating fluoroscopy baggage scanner devices at the Port. Based on the results of this study: no operational license for fluoroscopy baggage scanner, radiation workers operator didn't certify, they don't have personal monitoring dose, they get health monitoring but not well documented, radiation testing has not been carried out for radiation workers and passengers. Radiation exposure measurements using surveymeter detected both for passengers and radiation workers around the fluoroscopy baggage scanner device was declared safe because the radiation exposure rate detected was below 1 Sv/h (FDA), PP No. 33 of 2007, Perka Bapeten No. 7 of 2009 and Perka Bapeten No. 4 of 2013. But it can be optimized by lead glass or lead apron.
\end{abstract}

Keywords: Radiation Safety Standards; Fluoroscopy Baggage Scanner; Port

\section{Introduction}

Occupational Health and Safety work is one important aspect that needs serious attention because if it is ignored then accidents experienced by workers will result in decreased quality of work performed by the workers themselves and will affect the quality of service.

Indonesia is one of the island countries. So that to connect one area to another one of the cheaper modes of transportation is a ship that usually stops at the port. The port is a facility at the end of the ocean, river, or lake to receive ships and move cargo goods and passengers into them. Therefore, in the passenger terminal of a port it is equipped with a scanning tool for goods entering through the passenger terminal called fluoroscopy baggage scanner. Fluoroscopy baggage scanner equipment is detector equipment that is used to detect all prospective passengers' luggage at the port which can endanger the safety of passengers quickly without opening the packaging of the goods.

Port is also a gateway for entry into a certain area and as a connecting infrastructure between regions, between islands, even between countries [1]. For security at the port, one of them uses a tool called fluoroscopy baggage. Fluoroscopy Baggage as seen in figure 1 below.

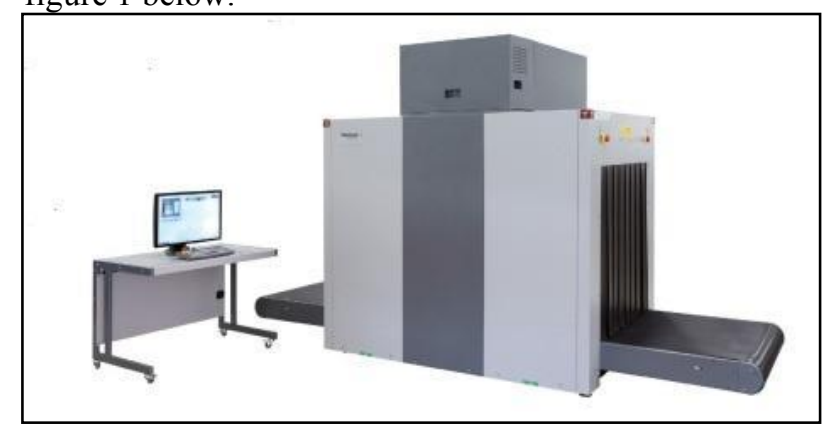

Fig. 1. Rapiscan 628 XR Aircraft Fluoroscopy Baggage [2]

Fluoroscopy baggage scanner is detector equipment that is used to detect all prospective passengers' luggage at the port which can endanger the safety of passengers quickly without opening the packaging of the goods.

Basic principles of fluoroscopy baggage scanner equipment:

1. Goods to be checked enter into the tunnel (tuning) system checks through conveyor belts (belt conveyors).

\footnotetext{
*Corresponding author: srimulyati@poltekkes-smg.ac.id
} 
2. The items to be inspected will be detected by a number of light barriers when the goods enter the tunnel.

3. The sensor detects incoming goods, then the sensor will send a signal to the control unit to activate the X-Ray.

4. X-rays will penetrate the objects that are in the walking unit (belt conveyors) as part of the inspection process.

5. The item to be inspected will absorb the light emitted by the generator (X-ray generator). The beam emitted will hit detectors on two sides of the tunnel.

6. The fan-shaped beam will penetrate the object that is on the conveyor belt (belt conveyor) piece by piece and the image signal received by the detectors will then be collected part and section and form a fixel on the monitor screen.

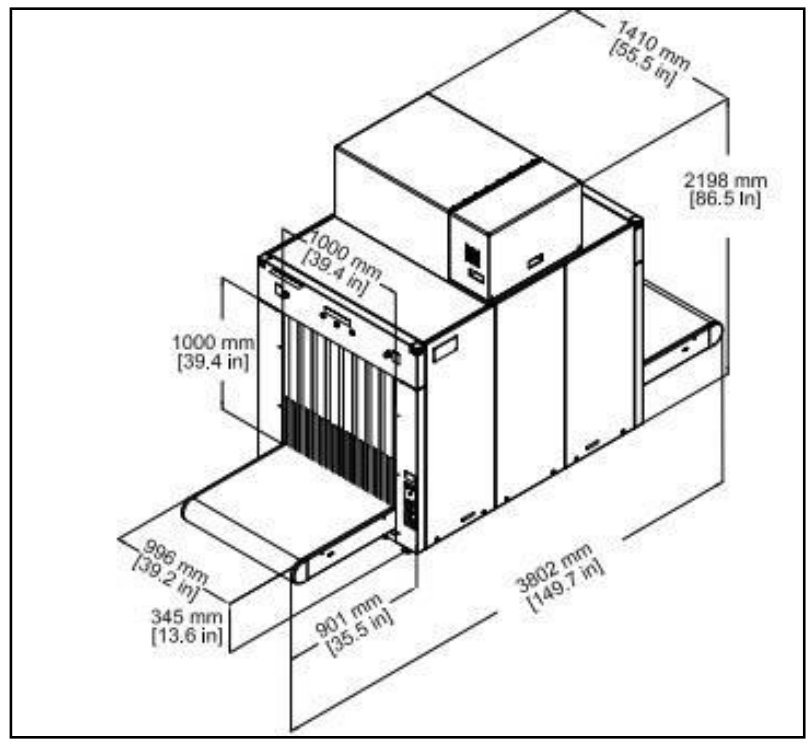

Fig. 2. Fluoroscopy Baggage Specifications Rapiscan 628 XR [2]

The front of the monitor in figure 1 is one of the positions of the radiation worker operator and other workers in front of the fluoroscopy baggage unit so that passengers put their luggage in the luggage and door fluoroscopy tunnel exit the other tunnel. If from the monitoring of the officer in front of the monitor there are dangerous passenger luggage such as sharp weapons, liquids, and other dangerous substances, the passengers who have the goods will be inspected by the port security officer.

In a fluoroscopy baggage scanner that uses X-ray type ionizing radiation operates with an anode tube voltage of $160 \mathrm{kV}$ and a tube current of $1.0 \mathrm{~mA}$ which radiates vertically downward. In addition, the performance of the generator has penetrating power (penetration) of $28 \mathrm{~mm}$ in steel guaranteed and $30 \mathrm{~mm}$ typically. So, it can be said fluoroscopy baggage scanner operates on low energy rays. The use of radiation in fluoroscopy baggage scanner is regulated by government regulation [3] concerning licensing for the use of ionizing radiation sources and nuclear materials in article 7 clearly stipulated that utilization of ionizing radiation sources group B letter $\mathrm{c}$ which includes the use and/or research and development in luggage fluoroscopy.

Fluoroscopy Baggage scanner operators are carried out by special staff who have received education or training [4] and have a Work Permit (SIB) as TPR 3Industrial PPR [5].

During work, operate a bag or fluoroscopy baggage scanner aircraft must use a personal monitoring dose such as a film badge, TLD Badge, or pen dosimeter. Furthermore, the style must be read and sent to the radiation dosimetry laboratory so that the dose obtained by radiation workers can be monitored properly should not exceed the threshold set by the government, namely the NBD of the radiation worker is $20 \mathrm{mSv} / \mathrm{yr}$.

This is in accordance with government regulation [6] article 21 which reads: "The dosage limit value for personnel should not exceed:

Effective dose of $20 \mathrm{mSv} / /$ th for 5 consecutive years

The effective dose of $50 \mathrm{mSv}$ in a given year equivalent dose for eye lens of $150 \mathrm{mSv}$ in one year, dose equivalent to the hands and feet or the skin of 500 $\mathrm{mSv}$ in one year, while in article 22 set the dose limit for the general public which may not exceed: the effective dose of $1 \mathrm{mSv}$ in one year dose equivalent to the lens eye $15 \mathrm{mSv}$ in 1 year. The equivalent dose for skin is 50 $\mathrm{mSv}$ in 1 year.

While article 23 states that the permit holder must ensure that the NBD is not exceeded by carrying out radiation exposure monitoring with surveymeter. Carrying out monitoring of dosage received by personnel with film badges or TLD badges, and calibrated pocket dosimeters, and provide radiation protection equipment Al 25 regulates radiation protection and safety optimization, which must be sought so that personnel and community members receive the lowest possible exposure that can be achieved, is a decision-making process to obtain the best scenario and optimal action taking into account technological, economic and social factors, and through dosage restrictions for personnel and society.

Regulations regarding radiation protection and radiation safety in the use of nuclear power that the NBD for radiation workers is $20 \mathrm{mSv} /$ year or equivalent to $0.0032 \mathrm{mSv} / 20 \mathrm{~min}$ [7]. While the regulations on safety and health on the use of ionizing radiation [4] articles $3,4,5$, and 6 regarding the dose limitation system. The radiation safety management system is regulated in article 7 which covers the organization of radiation protection, radiation dose monitoring and radioactivity, radiation protection equipment, health checks, document storage, and quality assurance as well as education and training. Article 29 concerning training for radiation workers.

During the operation of the fluoroscopy baggage scanner located in the port are radiation workers and the 
general public (passengers) or other port officers. People who are around this radiation field must be monitored from secondary radiation doses that radiate around luggage fluoroscopy during operation. This is in accordance with government regulations regarding radiation safety on industrial $X$ rays [8] concerning radiation safety and radioactive source security aimed at ensuring the safety of workers and community members, protecting the environment, and security of radioactive sources (Article 3). In article 4 [1], it is explained that every person or entity that will utilize nuclear power must have permission to use nuclear power and meet radiation safety requirements. Whereas in paragraph 3 describes the radiation safety requirements which include: management requirements (article 5), radiation protection requirements, technical requirements, and safety verification. In its operation, it must follow the radiation protection requirements contained in Article 21 which consist of justification, limitation, and optimization of radiation protection and safety.

Translation of regulation [8] includes: Management requirements (article 5) above include: person in charge of radiation safety, safety culture, health monitoring, personnel, education and training, and recording. Article 6 concerning the person responsible for radiation safety is the permit holder and other parties related to the implementation of nuclear power utilization. Article 8 regulates everything related to health monitoring for radiation workers which is carried out before work, during work, and will terminate employment according to article 9. While health checks for radiation workers must be conducted periodically at least once every year according to article 11. Dosage monitoring and dose evaluation must be submitted by the dosimetry laboratory to the permit holder and Bapeten workers must be carried out by the permit holder as referred to in Article 29 (paragraphs 1, 2, 3,4 and 5). Article 31 describes radiation protection equipment that must be provided by the permit holder. Article 32 Every radiation worker must use an individual dose monitor and radiation protective equipment.

Regulation on the safety and security of nuclear installations. In this government regulation (PP) include nuclear installation technical safety, nuclear installation security technical, nuclear plant safety and security management and nuclear emergency preparedness and response [9] (article 3). The technical safety of the installation includes site monitoring, design and construction, commissioning, operation, modification, decommissioning and verification and safety assessment as stipulated in article 4 of Article 9 governing design and construction. While the technicality of nuclear plant safety is regulated in article 43, including safeguards and physical protection.

Perka Bapeten on industrial radiation safety in article 3 radiographic equipment for open and closed facilities [10] as stated in article 3, licensing article 5,6,7,
8,9. Article 10 concerning radiation protection officers, article 12 concerning radiation safety requirements covering management requirements, radiation protection detailed in articles 21.22, 23, safety verification and techniques. Limitation of dosage related to NBD is regulated in articles 24.25 and 26 . The surveymeter radiation measurement is regulated in article 27.

Perka Bapeten concerning health monitoring for radiation workers in accordance with article 4 which includes: health checks (generally regulated in article 8 and specifically regulated in article 9) article 5, counseling, and/or health management of workers who are exposed to excessive radiation. Article 6 regulates the validity period of the health examination result, which is 1 year from the date the medical examination is conducted. Records of the results of complete health monitoring are regulated in article 25 [11]. While secondary radiation exposure recommended by the FDA America according to the user manual Rapiscan 628 XR is $1 \mathrm{~Sv} / \mathrm{h}$ [2]. According to regulation [8] above article 23 discusses the limitation of doses applied to work boards and public exposure through the application of dose limit values (NBD).

This limitation is also explained in article 23 (2) that the limitation of dosage does not apply to medical exposure and exposure that comes from nature. While the NBD of radiation workers is $20 \mathrm{mSv} / \mathrm{yr}$ for 5 consecutive years.

According to regulation [1], the use of radiation can have a negative effect on both genetic effects (effects arising from offspring) and somatic effects (which affect workers/people who are in the radiation field). The radiation effects that arise in humans are generally divided into two, namely: stochastic effects and non-stochastic effects. The stochastic effect is the result of the possibility of the effect on the offspring being dependent on the dose received by someone without a threshold value. While non-stochastic examples are skin cancer, leukemia, and infertility. To avoid this non-stochastic effect it is necessary to limit the dose value received by all body tissues [13].

No matter how small the radiation dose received by someone will have an effect. Based on the magnitude of the radiation dose If someone is exposed to radiation with a large dose of radiation it can cause direct effects (direct effect) or deterministic effects such as erythema and indirect effects (indirect effects) or also called stochastic effects. The deterministic effect occurs when the threshold dose is exceeded. While the stochastic effect usually occurs at low doses for a long time which is not immediately apparent for example cancer.

Therefore when we are in the radiation field we must be able to carry out radiation protection measures that cover distance, shield, and time. The distance, the farther we are from the radiation source, the safer. If we use shields or shields of radiation (shielding) then we will be protected from radiation. The longer we are 
exposed to radiation, the more accumulated doses. We must also apply the philosophy of radiation protection in the use of this radiation. The principles of radiation protection include justification, limitations, and optimization [7]. The Justification Principle is an activity that will not be carried out unless it has a positive advantage or is greater than the loss. The principle of limitation is that individual doses should not exceed the recommended limits of publication 103 and 105 ICRP for a particular environment. Principle of optimization is that radiation exposure is as low as possible which can be achieved by ALARA (as low achievable) by considering economic and social factors. Radiation concerning humans will have different effects depending on the sensitivity of their organs to radiation $[4,7,14$, $15]$.

\section{Methods}

This research method was carried out observational (Qualitative research). Data analysis of the three angulation techniques was analyzed qualitatively descriptive from the results of observation, documentation, interviews analyzed with interactive models. And the results of measurements of radiation exposure were analyzed with graphs then analyzed descriptively based on applicable regulations.

\section{Results and Discussion}

The fluoroscopy baggage scanner owned by the Port in this study was 2 pieces of luggage fluoroscopy. The single view Rapiscan 628 XR consisted of 2 pieces ( 1 in good condition and 1 damaged) in the terminal at the domestic terminal obtained from the grant of the Sea Transportation Ministry. According to the interview, the operating permit does not exist and does not meet the regulations ${ }^{[10]}$. This is because the status of baggage fluoroscopy is a grant from Dishubla. Possible licenses have not been submitted. Operators are not certified.

Fluoroscopy baggage operators are carried out by special staff who have received education or training [4] and have a Work Permit (SIB) as 3rd Industrial PPR [5]. The fact is that ports are not only trained for equipment operations and do not have SIB.

Ionizing Radiation is radiation that travels from an $\mathrm{X}$-ray tube and through an object without changing direction. The measurement of primary radiation exposure is measured using a calibrated DIGX Ram Ion measuring instrument. Measurement procedures are as follows:

1. Measuring instruments $\mathrm{ON}$ for exposure rates

2. Measurements are made on three areas, the far side of the generator, the center of the generator, and the near side of the generator

3. Measuring 3 times, then averaging radiation measurements background
4. Next to get a description of net: background radiation-measured radiation. Next, the results of the measurement are recorded as shown in table 1 .

Table 1. Primary Radiation Measurement with surveymeter ( $\mathbf{m S v} / \mathbf{h})$

\begin{tabular}{|l|l|c|r|l|}
\hline No & $\begin{array}{l}\text { Area } \\
\text { measured }\end{array}$ & Average & Background & $\begin{array}{l}\text { Radiation } \\
\text { Exposure }\end{array}$ \\
\hline 1 & Left & 4.68 & 0.00153 & 4.868 \\
\hline 2 & Central & 7.63 & 0.00153 & 7.628 \\
\hline 3 & Right & 8.90 & 0.00153 & 8.898 \\
\hline
\end{tabular}

At primary radiation exposure in the best condition x-ray luggage scanner with $150 \mathrm{kV}, 1 \mathrm{~mA}$ and $\mathrm{s}$ obtained from the conveyor belt speed of $0.2 \mathrm{~m} / \mathrm{s}$ divided by the length the conveyor belt trajectory is $2 \mathrm{~m}$ so the time is 10 seconds. Thus, the aircraft's operating conditions are $150 \mathrm{kV}, 1 \mathrm{~mA}$, and $10 \mathrm{~s}$. In primary radiation exposure, the biggest exposure is the rightmost side of the entrance passenger area near the generator which can be assumed as the anode side. While the middle part ranks second, and third is the far left side (cathode side). In addition, the internal components when opened from the generator inside are a kind of shielding form of a cone tube resembling a right triangle. The biggest side of radiation exposure is getting a large exposure, the middle is reduced due to the influence of shielding distance in the middle of the hypotenuse, and the lowest shielding at the end of the oblique side (cathode).

Secondary radiation is scattering radiation after $\mathrm{X}$ rays through an object, measurement is initially done with Ram Ion, but is not detected so that it shows a result of 0 . Furthermore, measured by another measuring instrument, the calibrated Babyline 81 Canberra surveymeter. In testing secondary radiation this must be observed carefully because the results will appear and disappear immediately. Measurements are carried out according to the operational procedures of the tool, and the measurement technique is carried out by a circular distribution technique from an angle of $0^{\circ}$ to $360^{\circ}$ from the source (source) with a distance of $1 \mathrm{~m}$. The angle range is a multiple of $30^{\circ}$, so that there are 12 points measured each of which is carried out three times the measurement. Then the background radiation measured in the scale x10 $\mathrm{Sv} / \mathrm{h}$ (actual measure) without any correction factor. Fk starts from the scale x100 Sv/h (fk 1.05) and scale $\mathrm{x} 1000 \mathrm{~Sv} / \mathrm{h}$ (fk 0.95). The measurement results obtained are averaged and further reduced by background radiation as shown in Table 2 
Table 2. Measurement of radiation exposure to Fluoroscopy baggage with a distance of $1 \mathrm{~m}$

\begin{tabular}{|c|r|c|}
\hline \multicolumn{1}{l|}{ No } & \multicolumn{1}{c|}{$\boldsymbol{\theta}$} & $\begin{array}{c}\text { Radiation Exposure } \\
\text { ( Sv / h) }\end{array}$ \\
\hline 1 & 0 & 0.7 \\
\hline 2 & 30 & 0.3 \\
\hline 3 & 60 & 0.23 \\
\hline 4 & 90 & 0.1 \\
\hline 5 & 120 & 0.1 \\
\hline 6 & 150 & 0.3 \\
\hline 7 & 180 & 0.1 \\
\hline 8 & 210 & 0.03 \\
\hline 9 & 240 & 0 \\
\hline 10 & 270 & 0.1 \\
\hline 11 & 300 & 0.1 \\
\hline 12 & 330 & 0.3 \\
\hline
\end{tabular}

Distribution of the dosage distribution of luggage fluoroscopy at the Port from a $0^{\circ}$ point in multiples of $30^{\circ}$ experiencing exposure variations from $0-90^{\circ}$ tend to experience this decrease is due to cone construction of $\mathrm{X}$-ray source generators. From an angle of $90^{\circ}-180^{\circ}$ it tends to rise from $0.1 ; 0.3$; and 0.6 and at point $180^{\circ}$ by 0.1 Decrease 0.1 due to the same distance of $1 \mathrm{~m}$ which is estimated as the source distance decreases due to cone-shaped shielding in internal fluoroscopy baggage construction. So the amount of radiation exposure at the baggage fluoroscopy at the Port passenger terminal is in addition influenced by the internal construction of the fluoroscopy baggage and the model of the shielding collimation which is shaped like a right triangle.

While we took source points from the appearance of the existing luggage fluoroscopy generator. Whereas what we set at $0^{\circ}$ is the largest exposure of 0.7 because the part is directly adjacent to the baggage fluoroscopy layer and outside air so only the metal fluoroscopic baggage that is not collimated is like the $180^{\circ}$ side of the point. Part $0^{\circ}$ to point $180^{\circ}$ is the collimated point as well as from point $180^{\circ}$ to $330^{\circ}$. Just returned to the point of $0^{\circ}$ or $360^{\circ}$ whose construction is slightly different because it is not double shielding. What is regulated from the generator is seen by measuring at a distance of $1 \mathrm{~m}$ in all directions.

The biggest part of the exposure is at $0^{\circ}$ by 0.7 $\mathrm{Sv} / \mathrm{h}$ and the smallest point at $0 \mathrm{~Sv} / \mathrm{h}$ at point $240^{\circ}$ means that the point is the thickest shielding point because in addition to measuring distance $1 \mathrm{~m}$ equal to all points but the construction of shielding collimation contribute to thickness and no shielding atoms so that they have the least radiation exposure.

Table 3. Measurement of radiation exposure to fluoroscopy baggage at a distance of $2 \mathrm{~m}$

\begin{tabular}{|c|c|c|}
\hline No & $\theta$ & $\begin{array}{c}\text { Radiation Exposure } \\
\qquad(\mathrm{Sv} / \mathrm{h})\end{array}$ \\
\hline 1 & 0 & 0 \\
\hline 2 & 30 & 0 \\
\hline 3 & 60 & 0 \\
\hline 4 & 90 & 0 \\
\hline 5 & 120 & 0 \\
\hline 6 & 150 & 0.1 \\
\hline 7 & 180 & 0.1 \\
\hline 8 & 210 & 0.03 \\
\hline 9 & 240 & 0.1 \\
\hline 10 & 270 & 0 \\
\hline 11 & 300 & 0 \\
\hline 12 & 330 & 0 \\
\hline
\end{tabular}

In table 2 the measurement of the radiation exposure distribution at a distance of $2 \mathrm{~m}$ is smaller when compared to the measurement of $1 \mathrm{~m}$ distance radiation exposure, as seen in table 2 . In table 2 , there is a dose distribution of $0 \mathrm{~Sv} / \mathrm{h}$ at $0^{\circ}, 30^{\circ}, 60^{\circ}, 90^{\circ}, 120^{\circ}$, $270^{\circ}, 300^{\circ}$ and $330^{\circ}$. While at points $150^{\circ}$ and $180^{\circ}$, $240^{\circ}$ at $01 \mathrm{~Sv} / \mathrm{h}$ and $210^{\circ}$ points as much as $0.03 \mathrm{~Sv} /$ h. Point $150^{\circ}, 180^{\circ}, 210^{\circ}$, and $240^{\circ}$ are the transition regions decreasing the cut-off triangular shape of the cone in the internal collation of fluoroscopy baggage measured in this circle method. If seen in figure 2 measurement of radiation exposure to luggage fluoroscopy at the passenger terminal of the port at a distance of $2 \mathrm{~m}$. distribution of exposure at a distance of $2 \mathrm{~m}$ produces radiation exposure of $0-0.1 \mathrm{~Sv} / \mathrm{h}$.

In Figure 3 above, the distribution of radiation exposure to fluoroscopy baggage is obtained at TE Port as seen in the graph. At a distance of $1 \mathrm{~m}$, the radiation exposure range is from 0.1 to $0.7 \mathrm{~Sv} / \mathrm{h}$. Whereas at a distance of 2 meters the radiation exposure distribution was obtained from 0 to $0.1 \mathrm{~Sv} / \mathrm{h}$. Exposure to background radiation (background is $0.1 \mathrm{~Sv} / \mathrm{h}$ ). So, at a distance of $2 \mathrm{~m}$, large radiation exposure is obtained which is the same as background radiation (background). 
The greater the distance, the less exposure to the radiation.

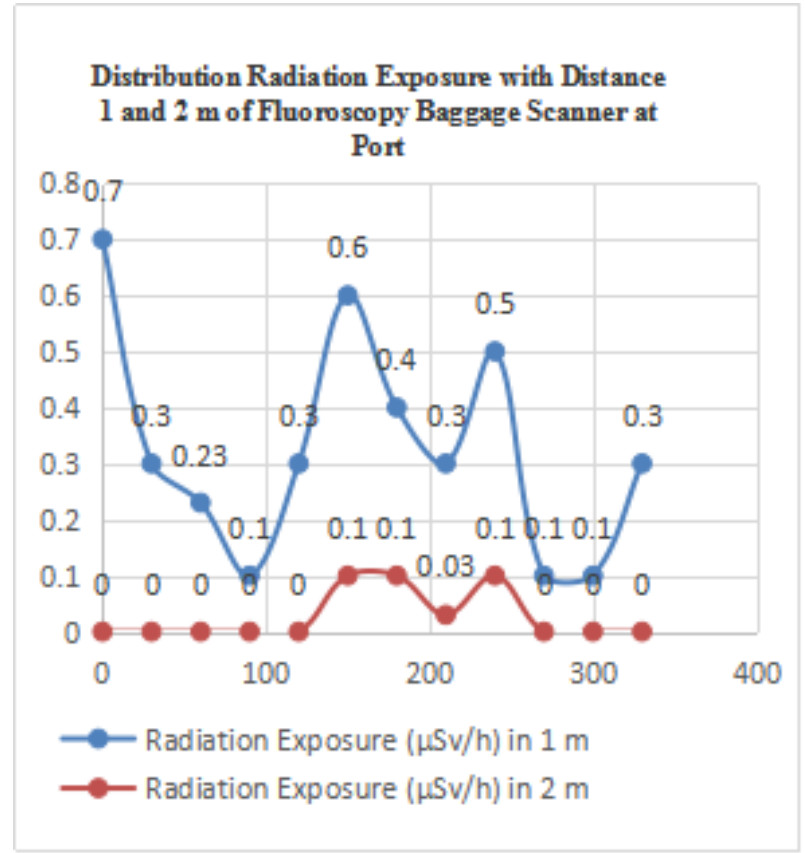

Fig. 3. Distribution radiation exposure at distances of 1 and $2 \mathrm{~m}$ of fluoroscopy baggage scanner in Port

Whereas according to table 3 if the measurement technique is circular in shape we measure clockwise starting from $0^{\circ}$ to $330^{\circ}$. In general, distance affects the amount of radiation exposure. At a distance of $2 \mathrm{~m}$, the magnitude of the distribution of radiation exposure is smaller than the distribution of radiation films at a distance of $1 \mathrm{~m}$. Both the radiation exposure distribution 1 and $2 \mathrm{~m}$ are below international standards (USA FDA referred to by Rapiscan $628 \mathrm{XR}$ ) at $1 \mathrm{~Sv} / \mathrm{h}(2)$.

Whereas when compared with the national standard for workers [8] that is equal to $10 \mathrm{~Sv} / \mathrm{h}$. This means that the greater the distance the radiation exposure is, the smaller the results of monitoring and evaluation at the time of operation of the fluoroscopy baggage scanner at this port are still safety based on the international standard of equipment which is still below $1 \mathrm{~Sv} / \mathrm{h}$. Whereas according to the national standard $10 \mathrm{~S} / \mathrm{h}$. This is based on fluoroscopy baggage scanner measurements with the circle method measured in area A having a dose distribution range of $0-0.7 \mathrm{~Sv} / \mathrm{h}$ at a distance of $1 \mathrm{~m}$. While at a distance of $2 \mathrm{~m}$ the distribution of exposure is smaller, namely $0-0.1 \mathrm{~Sv} / \mathrm{h}$. So it is still below the gold standard baggage fluoroscopy tool based on the USA FDA of $1 \mathrm{~Sv} / \mathrm{h}$ and based on national gold standards at $10 \mathrm{~Sv} / \mathrm{h}$ [8] and 20 $\mathrm{mSv} / \mathrm{h}[7]$.

Based on Figure 3, the farther the distance of the radiation source with the source and radiation workers or the general public who are in charge of the security port, the exposure to the radiation becomes smaller. However, even though the radiation exposure obtained is small it will cause a dose that accumulates for the body of radiation workers or the general public. So that at points that still produce radiation exposure, shielding for radiation workers such as monitoring glass made of $\mathrm{Pb}$ for officers at points 150,180 , and 210 should be added. It is best to protect radiation workers when they work permit holders should equip workers radiation with a personal monitoring dose such as the TLD Badge, Film Badge or pocket dosimeter. Furthermore, the exposure received can be monitored periodically by sending a personal monitoring dose to an accredited dosimetry institution (BATAN / BPFK).

The use of radiation can cause effects such as genetic effects (effects arising from offspring) or somatic effects (which affect workers/people who are in the radiation field [12]. The radiation effects that arise in humans are generally divided into two, namely: stochastic effects and non-stochastic effects. The stochastic effect is the result of the possibility of the effect on the offspring being dependent on the dose received by someone without a threshold value. While non-stochastic examples are skin cancer, leukemia, and infertility. To avoid this non-stochastic effect it is necessary to limit the dose value received by all body tissues [13].

While at the terminal, the passengers work in shifts and not every day the ship departs. So, automatic radiation exposure received by radiation workers (X-ray operators) in the Port is very small. Because the ship's departure schedule can be 2-3 times a week and is divided into shifts with 10 officers. If the management of port does want as an international standard passenger terminal based on the results of this study, it is necessary to arrange management regarding the use of X-rays fluoroscopy baggage scanner in the passenger terminal.

This arrangement is related to applicable regulations, HR, radiation protection and the effects that can be caused due to radiation utilization, especially for radiation workers. The slightest effect will have an impact that is not visible now but will appear for some time the stochastic effect of both cancer and genetic disorders. Because of this effect, changes in radiobiology can affect cells, tissues, organs, organ systems, and the whole body. Cellular changes that occur can be overcome by foods that contain protein high. The alternative that can be done is giving additional hiprotein food for radiation workers. For the consequences/hazards of the possibility of radiation utilization on workers can be adjusted by management regarding radiation hazard benefits and periodic health checks.

While the operator of fluoroscopy baggage scanners should be given standardized and certified training and knowledge as well as technical uses of tools as well as insight into radiobiology (the effects of radiation on human biology) and radiation protection management [13]. Monitoring personnel dosage is given so that the doses received can be recorded and can be evaluated based on the NBD of radiation workers to meet existing 
regulations $[4,8]$, and have a Work Permit (SIB) as Industrial PPR 3 [5]. In this study, the highest radiation exposure around fluoroscopy baggage scanner was 0.7

$\mathrm{Sv} / \mathrm{h}$., If converted to $\mathrm{mSv} 0.0007 \mathrm{mSv} / \mathrm{h}$. While passengers only get exposure when in the vicinity of fluoroscopy baggage scanner in just seconds. So, for the general public who are around fluoroscopy baggage scanner it is still safe because it is in accordance with international regulations $<1 \mathrm{~Sv} / \mathrm{h}$ at a distance of $1 \mathrm{~m}$ $[2,7,8]$. But it would be better if we optimize it by adding shielding to fluoroscopy baggage scanner operators and other security port officers so that the exposure becomes zero with $\mathrm{Pb}$ glass shields or using lead aprons for officers.

Thus the protection of workers and the general public has been optimized so that it will reduce the occurrence of non-stochastic effects that can cause skin cancer, leukemia, and infertility. This is due to low exposure but accumulates in the body for a long time.

\section{Conclusion}

Implementation of fluoroscopy baggage scanner at the port passenger terminal since 2017, but does not yet have a permit and is not in accordance with regulations that have HR operating fluoroscopy baggage scanner yet to receive training licensed by BAPETEN as the 3rd industrial X-ray radiation worker and do not have a work permit (SIB).

Periodic health checks at least 1 year is already done, but it has not been documented and evaluated associated with radiation exposure has never been personnel monitoring dose and radiation workers are not using personnel monitoring dose of good film badge, TLD badge and, dosimeter pocket has never been tested exposure to worker exposure and public exposure. Based on the results of monitoring and evaluation of fluoroscopy baggage scanner operating in passenger terminals resulting in safe radiation exposure based on national and international regulations. But it can be optimized by adding $\mathrm{Pb}$ (lead glass) to the operator room and fluoroscopy baggage scanner officers when working using a lead apron.

\section{References}

1. Triatmodjo. Bambang. Perencanaan Pelabuhan. Yogyakarta : Beta Offset (2009).

2. Anonim. Rapiscan 628 XR Baggage and Parcel Inspection diakses pada https://pg-co.com/wpcontent/uploads/2014/11/Rapiscan-

628XR_Screen.pdf tanggal 2 januari 2018

3. Peraturan Pemerintah, 2008, PP No. 29/2008 tentang Perizinan Pemanfaatan Sumber Radiasi Pengion dan Bahan Nuklir (2008)

4. PP No 63 tahun 2000 tentang Keselamatan dan kesehatan terhadap pemanfaatan radiasi pengion (2000)
5. Bapeten, Perka Bapeten No. 16 Tahun 2014 tentang Surat Izin Bekerja Petugas Tertentu yang bekerja di Instalasi yang Memanfaatkan Sumber Radiasi Pengion (2014)

6. Bapeten, Perka Bapeten No. 9 Tahun 2009 tentang Intervensi terhadap Paparan yang berasal dari Technologically Enhance Naturally Occuring Radioctive Material (2009)

7. Bapeten, Perka Bapeten No. 4 Tahun 2013 tentang Proteksi dan Keselamatan Radiasi dalam Pemanfaatan Tenaga Nuklir (2013).

8. Peraturan Pemerintah, PP No. 33/2007 tantang Keselamatan Radiasi Pengion dan Keamanan Sumber Radioaktif (2007)

9. Peraturan Pemerintah, 2012, PP No. 54/2012 tentang Keselamatan dan Keamanan Instalasi Nuklir (2012)

10. Bapeten. Perka Bapeten No 7 tahun 2009 tentang Keselamatan Radiasi Dalam Penggunaan Peralatan Radiografi Industri (2009)

11. Bapeten, Perka Bapeten No. 6 Tahun 2010 tentang Pemantauan Kesehatan untuk Pekerja Radiasi (2010).

12. Bapeten. Pendidikan dan Pelatihan Petugas Proteksi Radiasi. Jakarta (1997).

13. Bapeten. 2005. Petugas Proteksi Radiasi.Jakarta

14. ICRP. ICRP Recomendation in publication 103 radiological protection in medicine (2007).

15. ICRP. ICRP Recommendation publication 105 ALARA principles (2007) 